\title{
Financial Administration and Small and Medium Enterprises: A Study Conducted in South Africa
}

\author{
By Thea Visser* \\ Gideon Nieman \\ Emsi van Heerden
}

\begin{abstract}
This study focuses on financial administration issues and processes that are used by the owners of small and medium enterprises. This study evaluates the extent to which financial administration is conducted and attempts to establish whether the information that is obtained through financial administration is used for cash-flow management and forecasting. In this study, we shall also investigate the effect that financial administration has on the tax compliance of small and medium enterprises. The sample consisted of 118 small and medium enterprises in South Africa. Businesses included in the sample frame confirmed to the requirements of a turnover of $R 2$ million and less per annum, and a maximum of 50 employees. The findings highlight that financial administration is conducted, and that tax compliance is influenced by an enterprise's financial administration. The findings also show that sound financial planning contributes to the overall implementation and success of the principles of financial administration as these are applied by small and medium enterprises in South Africa.
\end{abstract}

Keywords: Entrepreneurship, Financial administration, Financial management, Small and medium enterprises, South Africa

\section{Introduction}

Entrepreneurship is an important economic and social phenomenon. The economic contributions of entrepreneurship are widely accepted as being significant (Autio 2011). From the perspective of public policy, arguably the most important aspect of any new businesses concerns its ability to create jobs and job stability. New businesses are responsible for up to one third of net job creation in South Africa. According to Autio (2011), however, numerous studies suggest that only a relative small proportion of all new businesses are responsible for creating the majority of new jobs. Only less than $10 \%$ of all new businesses are responsible for between $50 \%$ and $75 \%$ of all new jobs created by new businesses. Hatten (2012) claims the most common causes of

\footnotetext{
* Senior Lecturer, Department of Business Management, University of South Africa, South Africa.

${ }^{\dagger}$ Professor, Department of Business Management, University of Pretoria, South Africa.

* Post-graduate Student, Department of Business Management, University of Pretoria, South Africa.
} 
business failure are inadequate management and financing. High operating expenses and inadequate profit margins reflect ineffectiveness on the part of an enterprise's management. Furthermore, business failure due to insufficient capital suggests inexperience on the part of management. Business failure due to inadequate financing is caused by both improper managerial control and a shortage of capital. Finally, an inaccurate estimate of cash flow and capital requirements can quickly lead to the downfall of any business. To reiterate small businesses have been identified as a key driving force for economic growth in South Africa. The South African government's strategy is to curb unemployment through job creation, to alleviate poverty and to redistribute wealth (Finmark Trust 2010a). Finmark Trust (2010b) reported that there were 5,579,767 small business owners during 2010 who, between them, owned $5,979,510$ small businesses. Furthermore, during 2010, small businesses created 11,605 million employment opportunities in South Africa (2010b). A total of $39 \%$ small business owners cite money-related matters as the main obstacle to starting up a business, while $34 \%$ cite business strategy matters as their main obstacle (i.e. determining and finding what to sell, finding their target market, and dealing with competitors) (Finmark Trust 2010a).

Very little research has been conducted in South Africa on the financial issues of SMEs. This study attempts to fill this gap. The purpose of this paper is to report on a study which investigated whether or not essential financial management processes are practised by small and medium enterprises (SMEs) in South Africa. The study attempted to establish if the information obtained through financial administration is used for the purposes of cash-flow management and cash-flow forecasting. Furthermore, the study attempted to establish the influence of inefficient financial management on the health of a business, including the influence of inefficient financial administration on tax compliance.

This paper starts with a theoretical overview of the study, followed by the methodology, a discussion of the results and, finally, the conclusion.

\section{Literature Review}

In the context of SMEs, it is important to have clarity regarding concepts, the context, and the constraints experienced in the entrepreneurial environment. We have also provided information on financial management, administration, recordkeeping and certain tax-related issues.

\section{Entrepreneurial Environment Concepts}

The terms "enterprise", "entrepreneurs", "entrepreneurial activity" and "entrepreneurship" are all found in the literature. Down (2010) claims that an enterprise consists of entrepreneurship, and may refer to a small business, a micro-business, the self-employed and all the various contexts in which these are found. An enterprise is defined as "an alternative term for a commercial organisation or firm, as in the expression SME" (Blundel and Lockett 2011). 
Entrepreneurship is defined as "any attempt at a new business or new venture creation, such as self-employment, a new business organisation, or the expansion of an existing business by an individual, a team of individuals, or an established business" (Bosma et al. 2012). The National Small Business Amendment Act, 29 of 2004 (South Africa 2004), defines a small business organisation as:

"..... any entity, whether or not incorporated or registered under any law, (which consists) consisting mainly of persons carrying on small (business) enterprise concerns in any economic sector (or which has been) and established for the purpose of promoting the interests of or representing small (business) enterprise concerns in any economic sector (or which has been) and established for the purpose of promoting the interests of or representing small (business) enterprise concerns, and includes any federation consisting wholly or partly of such association, and (also) any branch of such organisation".

SMEs are classified according to their total full-time equivalent of paid employees, total annual turnover, and total gross asset value (fixed property excluded) (South Africa 1996). Generally speaking, a small business has fewer than 50 employees and an annual turnover of less than R2.5 million (University of Pretoria 2009).

\section{Entrepreneurial Environment: Context}

South Africa's participation in the 2011 Global Entrepreneurship Monitor (GEM) study led to the country obtaining an Entrepreneurial Employee Activity (EEA) rate of $0.3 \%$, which is significantly lower than the average of $1.8 \%$ for efficiency-driven economies. The formal South African employment environment exhibits very low levels of entrepreneurship (Simrie et al. 2011). Note that the country's economic, social and political challenges have increased over the last decade, which is evidenced in the growing unemployment figure, service delivery protests and mounting concerns about corruption, crime and governance. Despite South Africa's many achievements over the last 10 years, the country's poverty levels remain unacceptably high, particularly when compared with other emerging economies (Simrie et al. 2011).

South Africa's rate of entrepreneurial intentions is very low (17.6\%). Given South Africa's high unemployment rate $(23.9 \%)$, it is a matter of some concern that only a few individuals want to engage in any form of entrepreneurship (Simrie et al. 2011). Government policies, financial support, and education and training are the most significant factors limiting entrepreneurship in South Africa (Simrie et al. 2011). Furthermore, an inefficient government bureaucracy is a problematic factor for anybody contemplating doing business in South Africa, while government taxes and regulations are also limiting factors. Another problem is the issue of Black Economic Empowerment (BEE) - this is a government policy that is viewed as 
a significant impediment to business growth. Access to financial support limits entrepreneurial activity in South Africa, specifically because of a lack of venture capital funding and investors and because of the limited availability of "affordable money" (Simrie et al. 2011).

\section{Entrepreneurial Environment: Constraints}

Nearly all entrepreneurial businesses face financial problems during their early years, and this fact makes finance and the practice of sound financial management critical to the survival and success of emerging businesses. Financial distress occurs when cash flow is insufficient to meet an entity's current liability obligations (Melicher 2012). Kerr and Nanda (2011) arrive at a similar conclusion, noting that financial constraints are one of the biggest concerns influencing potential entrepreneurs. Kerr and Nanda (2011) also claim that there are important frictions in the credit markets that effectively preclude high-quality entrepreneurs with good ideas (positive net present value projects) from entering product markets. These entrepreneurs are simply unable to access adequate capital that would enable them to start a new business. Much of the academic literature focuses on analysing the nature of these frictions, the effect they have on access to finance, and the impact of reduced financing constraints on the rates of entrepreneurship. Okpara (2011) points out that a lack of capital and financial resources is a major obstacle in business development. However, research on the role of capital in determining the success or failure of businesses in Africa is contradictory, and therefore remains unclear. A lack of basic business management skills (e.g. bookkeeping and inventory management) means that business owners end up losing track of their daily transactions, and being unable to account for their expenses and profits at the end of the month (Okpara 2011).

\section{Financial Management and Administration}

Entrepreneurial finance involves the application and adaptation of financial tools and techniques and the principles of the planning, funding, operations and valuation of an entrepreneurial business. It focuses on the financial management of a business as it moves through the entrepreneurial process (Melicher 2012). The administrative function of a business is concerned with obtaining, recording and analysing information, and communicating the results to management who safeguard the assets, promote the activities and achieve the objectives of the business (De Beer 2012). Financial management consists of those activities that create and preserve the economic value of the assets of an individual or small business and, in the end, comes down to the making of sound financial decisions (Brooks 2010).

According to Petty et al. (2012), an entrepreneur's decisions play out in four ways when evaluating the financial performance of the business. These ways include: the ability to pay debt when it becomes due, the business's profitability from assets, the amount of debt that the business is using, and the rate of return that is earned by the owners on equity investment. Hisrich et al. (2010) support the notion that key financial areas include a cash flow, and an 
income statement and a balance sheet. According to Hisrich et al. (2010), the most difficult problem in projecting cash flows is to determine the monthly receipts and disbursements. Many businesses experience difficulties with their projections owing to, firstly, a mismatch in time between receiving cash, and, secondly, a mismatch between the size of payments received, and the size of payments that need to be made (Katz and Green II 2011).

The income statement is the primary source of information about a business's profitability. Difficulties in interpreting the income statement include possible disagreements about what should be reported as revenue, and disputes over when to recognise revenues. The balance sheet is a "snapshot" of the financial holdings and liabilities at the close of business on a specified date and details the accounting equation of the business. The balance sheet is used to determine liquidity, financial flexibility and the financial strength of the business (Katz and Green II 2011). Hatten (2012) claims that, although some entrepreneurs are well versed in determining their need for capital and knowing where to find it, the failure of many businesses are traced to undercapitalisation not having the funds needed to get started and carry one until the business produces a positive cash flow.

\section{Recordkeeping and Taxation}

One in every two small business owners in South Africa keep financial records for their businesses, while $81 \%$ of business owners do it themselves (Finmark Trust 2010b). Byrd and Megginson (2009) provide the following reasons for keeping business records: tax and other records are required by law, and proper records help to manage a business more effectively.

Government taxation policies are not fixed, and changes in tax rates and related regulations have a significant effect on all businesses. New forms of taxation might be encountered as the business develops, and it might be difficult to understand the implications of these new forms of taxation on the business (Blundel and Lockett 2011). Taxes on the income of individuals account for $60 \%$ of the total taxes on income and profits in South Africa (Steenekamp 2011a). South Africa has, since 2006, improved the tax burden for businesses by eliminating, merging or reducing the frequency of required filings and payments (Doing Business 2011). However, the Association of Chartered Certified Accountants and the South African Institute of Tax Practitioners argue that further simplification of South Africa's tax laws, with particular focus on small businesses, could stimulate the economy and promote job creation (Temkin 2011). Herrington, Kew et al. (2010) claim that "the South African Revenue Services" Small Business Company tax break (also known as Graduated Tax on Small Business Companies) is a generous, well designed and increasingly used incentive. Steenekamp (2011b) reports that the tax system influences SMEs in South Africa because these businesses are highly dependent on working capital that is provided by owners. When business owners' profits are taxed, they often resort to short-term debt and thus increase their risk exposure. Various options could be pursued to assist the business through the tax system, including taxing businesses on their cash 
flow, taxing the business at differentiated rates (a progressive corporate rate structure), and using tax incentives (tax holidays and accelerated depreciation allowances). In 2000, the South African government opted for a graduated tax rate structure and generous depreciation allowances for small businesses. The tax rate structure for small businesses in South Africa is shown in Table 1.

Table 1. Graduated Tax Rate Structure for Small Businesses In South Africa

\begin{tabular}{|c|c|}
\hline Taxable income & Tax rate \\
\hline R0 - R59,750 & $0 \%$ \\
\hline R59,751 - R300,000 & $10 \%$ of amount above R59,750 \\
\hline R300,001 + more & R24, 025 plus 28\% of amount above \\
\hline
\end{tabular}

Source: SARS (2011).

As far as the administrative burden of complying with taxes (in South Africa) is concerned, the figures are as follows: on average, businesses make nine tax payments a year, spend 200 hours a year on filing, preparing and paying taxes, and pay a total in taxes amounting to $24.4 \%$ of their profit. Globally, South Africa stands at 44 in the ranking of 183 economies on the ease of paying taxes (The World Bank 2012).

\section{Research Methodology}

The objectives of the study were to establish the extent to which financial administration was practised by selected SMEs in South Africa, to establish the financial administration used by SMEs, and to find out whether any aspect was deficient in any way. In this study, we also examined whether or not the information obtained through financial administration was used to do cashflow management and cash-flow forecasting, and we investigated the effect of financial administration on SME tax compliance.

Once the data was obtained, it was subjected to a descriptive analysis. Businesses included in the sample frame conformed to the requirements of businesses with a turnover of R2 million and less, with not more than 50 employees. The sampling method used was non-probability sampling, and convenience and snowball sampling techniques were used. The SMEs were identified from local business directories. The questionnaire was pre-tested by five SME owners, which led to the rephrasing of some questions. The questionnaire consisted of 42 questions, divided into sections, and included open-ended and closed questions, rating questions, and Likert-type scale questions ranging from 1 (Strongly disagree) to 5 (Strongly agree). A total of 126 self-administered questionnaires were distributed, 120 questionnaires were received, of which 118 were used in the study as these had been completed in full. The measurement scales were tested in terms of both validity and reliability. Content validity was determined on the grounds of the researchers' collective judgement, and the evaluation was done by two statistical analysts 
from the University of Pretoria, South Africa. Answers to the questions were edited, coded and cleaned for the purposes of statistical analysis.

\section{Results}

The findings are shown and discussed in five sections: (1) demographic information, (2) business information, (3) respondents' banking arrangements and cash profiles, (4) financial administration, and (5) tax compliance.

\section{Demographic Information}

Gender of respondents: female (53\%), male (47\%). Racial composition: white $(52 \%)$, black (36\%), Indian $(9 \%)$ and coloured $(3 \%)$. The highest age range was 30 to 39 years (30\%), younger than 29 years $(25 \%), 50$ to 59 years (23\%), 40 to 49 years (20\%) and 60 years and older (2\%).

Most respondents had Grade 12 as their highest academic qualification (44\%). Of the remaining, the statistics are as follows: diploma (21\%), degree $(15 \%)$, post-graduate degree (12\%), and below Grade $12(8 \%)$.

\section{Business Information}

Most respondents were the owner of the business (49\%), an employee (29\%) or manager $(22 \%)$. Most businesses had fewer than ten full-time employees (69\%). Others had between 11 and 20 employees (14\%), between 20 and 29 employees (10\%), between 40 and 49 employees (4\%) and between 30 and 39 employees (3\%). Most businesses were between 1 and 4 years old (32\%), between 5 and 9 years (31\%), 10 years and older (26\%) and less than 1 year $(11 \%)$.

The sales of goods and services had the highest score as the business's industry $(68 \%)$. Others were: manufacturing $(6 \%)$ and food $(5 \%)$. Construction, automotive, engineering, financing, property, and health and beauty were equally rated (3\%), and legal, farming. and technology were equally rated $(1 \%)$.

The most popular form of ownership was the Closed Corporation (41\%), company (40\%), sole proprietor $(11 \%)$, and partnership (5\%). Some businesses were not registered $(2 \%)$, and some were non-profit organisations $(1 \%)$.

Most businesses had a turnover of less than R100,000 per annum (36\%). Others had between R1 million and R2 million (25\%), between R100,000 and R249,000 (17\%), between R500,000 and R749,000 (9\%), between R250,000 and R499,000 (7\%), and between R750,000 and R999,000 (6\%).

\section{Banking and Cash Profile}

Most respondents had a bank account for the business (86\%), while remaining respondents were without an account (14\%). Most respondents did not have an overdraft facility on the bank account used by the business (68\%), while $32 \%$ had this facility. Most respondents had not exhausted their overdraft facility in the past year (82\%), while $18 \%$ had exhausted this facility.

Most respondents had experienced a cash shortfall during the last four years and more (39\%). Some had never experienced a cash shortfall (19\%), 
while some had experienced a cash shortfall during the last year, and two and three years respectively (14\%).

Late payment of debtors was the main reason for experiencing a cash shortfall $(59 \%)$, followed by poor record-keeping (21\%), recession (8\%), tax obligations $(3 \%)$, growth and start-up requirements (2\% respectively), and pressure from creditors, loan requirements, theft, cash-flow problems and increase in cost were equally rated $(1 \%)$.

Most respondents disagreed that the business was refused credit or finance owing to a lack of business records (55\%), while the remaining respondents agreed $(45 \%)$.

\section{Financial Administration}

Most respondents kept financial records (98\%), and most respondents rated the overall quality of their financial records as good (49\%), excellent $(45 \%)$, fair $(5 \%)$, and poor $(1 \%)$. The most popular financial record-keeping system was a computer system $(71 \%)$, a hybrid system (computer and paper based) (19\%), and paper-based system (10\%).

Record-keeping elements were rated in terms of their importance. Stock control (100\%) and control of expenses (100\%) were scored as very important. Compliance with tax law had the highest score as important $(25 \%)$.

Business owners indicated that they always maintained their financial record-keeping system $(71 \%)$. The in-house bookkeeper never maintained the financial record keeping systems $(83 \%)$. Most respondents indicated the size of the business as the reason for maintaining the financial record-keeping system in this way (80\%), followed by internal expertise within the business (37\%), cost of hiring an accountant or bookkeeper (25\%), external expertise (1\%) and most practical manner (1\%).

Computerised records and payroll were maintained in-house $(86 \%$ respectively), and tax reporting was conducted in-house (51\%). Annual financial reports were conducted in-house $(53 \%)$, while annual tax returns were conducted in-house $(50 \%)$, and externally $(50 \%)$.

Computerised records were updated weekly (39\%), tax reporting monthly (49\%), while annual tax returns (39\%) and financial reports $(41 \%)$ were prepared yearly.

Most respondents spent between 0 and 19 hours per month on maintaining record-keeping systems and obtaining information for the accountant or bookkeeper $(24 \%)$. This was followed by between 20 and 39 hours (17\%) between 60 and 79 hours (17\%), between 40 and 59 hours (16\%), between 80 and 99 hours (16\%), between 100 and 119 hours (3\%), between 160 hours and more (3\%), between 120 and 139 hours (2\%), and between 140 and 159 hours $(2 \%)$.

The monthly costs $(\mathrm{R})$ of the business in maintaining the record-keeping system were between R500 and R4,999 (42\%), between R1 and R499 (35\%), between R5,000 and R9 999 (13\%), between R10,000 and R14,999 (5\%), R20,000 and more (4\%), and between R15,000 and R19,999 (1\%). 
Record-keeping elements with the highest scores were maintained as follows: pro-active debtor management records were updated daily $(15 \%)$, records of receipt weekly $(81 \%)$, pro-active debtor management also monthly (55\%), bank statements quarterly (69\%), and cash-flow statements yearly (8\%).

Respondents indicated that debtor records (accounts receivable) were prepared to pro-actively follow-up on debtors monthly (55\%), weekly (21\%), daily $(15 \%)$, yearly (3\%), quarterly $(3 \%)$ and never $(3 \%)$.

Respondents used a cash book or cash-flow statements for decisionmaking on a monthly basis (54\%), daily (16\%), weekly (15\%), quarterly (9\%), and never $(6 \%)$.

Cash-flow forecasting and analysis were done monthly (55\%), followed by quarterly (14\%), weekly (13\%), daily (9\%), never (8\%), and yearly (1\%).

Respondents strongly agreed with all of the following statements: The time dedicated to keeping records up to date exceeds the benefits (41\%). Respondents were confident in the accuracy of their record-keeping (57\%), and believed that they had the necessary financial record-keeping systems in place to comply with taxation laws $(63 \%)$. Financial record-keeping requirements for small businesses were time consuming (47\%), and financial record-keeping helped them to manage their business more effectively (69\%). A strong relationship existed between poor financial record-keeping and business failure (67\%), and good financial record-keeping reduced likelihood of a tax audit by SARS (69\%). Good financial record-keeping reduced the business's compliance $(63 \%)$, while good financial record-keeping ensured that a cash shortfall was avoided (64\%). Poor financial record- keeping prevented the business from obtaining the allowable tax deduction over the last three years $(44 \%)$.

\section{Tax Compliance}

The submission of tax requirements on a yearly basis were the highest for turnover tax (61\%), while provisional tax had the highest score for being submitted on a quarterly basis (23\%). Unemployment Insurance Fund (UIF) was submitted on a monthly basis (64\%), while UIF was also submitted on a weekly basis (3\%). Value-Added Tax (VAT) and Pay As You Earn (PAYE) had the highest score for being submitted daily (20\% respectively), while environmental levy had the highest score for never being attended to (25\%). Skills levy and capital gain tax were not referred to as they had low scores in all categories (daily, weekly, monthly, quarterly and yearly).

\section{Conclusion}

SMEs practise financial administration. Respondents who practise financial administration were shown to be more likely to be tax compliant than respondents who do not practise financial administration. Tax compliance is influenced by the extent to which financial administration is practised by SMEs in South Africa. 
The government should continue to implement and support legal systems, tax policies, and ensure a regulatory environment that is conducive to entrepreneurship. All people should be treated equally. This view is supported by Holcombe (2007), who claims that if some groups of people are favoured under the law, incentives for productive entrepreneurship are diminished. The product of a person's efforts is becoming vulnerable to predation by those who are favoured by a corrupt legal system (Holcombe 2007).

Well-structured financial plans provide the business with a complete picture of how much the business is worth, when funds are coming into the business, on what the funds are spend, how much cash is available, and the projected financial position of the business. Business owners should have adequate cash on hand to pay bills when they are due and payable. Proper budgetary control should be conducted, and this includes close control in areas where poor performance has a detrimental impact on the business. Past-due accounts should be monitored regularly so that slow accounts are followed up promptly, and incentives could be offered to slow-paying customers for earlier payment. Fixed business costs must be kept as low as possible and variable expenses should be tied to the revenue to ensure that expenses decline when income declines. Business owners should understand the tax environment in which they operate so that they can take full advantage of tax-related opportunities such as deductions, credits and tax savings. Tax decisions to be considered include the method of handling income and expenses, time period for paying taxes, and form of business ownership to use.

SME employees need to understand business operations - the general patterns of generating cash flows and outflows - because this helps to maintain an accurate forecast of cash needs. A training point for employees is how to perform financial administration and what records to be kept. Employees should realise the impact of financial administration on credit and loan approvals, tax compliance and the overall health of a business. Financial planning is critical for business success and, as Melicher (2012: 20) contends, the bottom line of all financial efforts is to increase the overall value of the business.

Future research directions include the influence of cash-flow management on SMEs' forecasting and decision-making. Another research area is establishing the reasons why businesses fail to comply with tax requirements. Skills and subsequent training for SMEs could be investigated, including accessibility of training, time spent on training, and the implementation of training for a specific ethnic group.

\section{Bibliography}

Autio E (2011) High-aspiration entrepreneurship. In: M. Minniti (ed.) The Dynamics of Entrepreneurship, Evidence from the Global Entrepreneurship Monitor Data. New York: Oxford University Press.

Blundel R, Lockett N (2011) Exploring entrepreneurship practices and perspectives. New York: Oxford University Press. 
Bosma N, Wennekers S, Amoros JE (2012) Global Entrepreneurship Monitor 2011 Extended Report: Entrepreneurs and Entrepreneurial Employees across the Globe. London: Global Entrepreneurship Research Association.

Brooks RM (2010) Financial Management Core Concepts. Boston, USA: Pearson Education, Inc.

Byrd MJ, Megginson LC (2009) Small Business Management, An Entrepreneur's Guidebook (6 ${ }^{\text {th }}$ ed.). New York: McGraw Hill.

De Beer A (2012) Basic business concepts and the business environment. In: J. Strydom (ed.), Entrepreneurship and How to Establish your Own Business $\left(4^{\text {th }}\right.$ ed.). Cape Town: Juta and Company Ltd.

Doing Business (2011). Report. Available from: http://bit.ly/1lYtE4S. [Accessed: 9 May 2012].

Down S (2010). Enterprise, Entrepreneurship and Small Business. London: SAGE Publications Ltd.

Finmark Trust (2010a). FinScope South Africa Small Business Survey 2010 Brochure. Johannesburg: FinMark Trust.

Finmark Trust (2010b). FinScope South Africa Small Business Survey 2010 Report. Johannesburg: FinMark Trust.

Hatten TS (2012). Principles of Small Business Management ( $5^{\text {th }}$ ed.). USA: SouthWestern, Cengage Learning.

Herrington M, Kew J, Kew P (2010) Global Entrepreneurship Monitor. Cape Town: Graduate School of Business, University of Cape Town.

Hisrich RD, Peters MP, Shepherd DA (2010) Entrepreneurship ( $8^{\text {th }}$ ed.). New York: McGraw-Hill/Irwin.

Holcombe RG (2007) Entrepreneurship and Economic Progress. New York: Routledge.

Katz JA, Green II RP (2011). Entrepreneurial Small Business ( $3^{\text {rd }}$ ed.). New York: McGraw-Hill/Irwin.

Kerr WR, Nanda R (2011) Financing constraints and entrepreneurship. In: DB Audretsch, O Falck, S Heblich A Lederer (ed.). Handbook of Research on Innovation and Entrepreneurship. Cheltenham: Edward Elgar.

Melicher L (2012) Entrepreneurial Finance ( $4^{\text {th }}$ ed.). USA: South-Western Cengage Learning.

Okpara JO (2011) Factors constraining the growth and survival of SMEs in Nigeria, implications for poverty alleviations. Management Research Review 34(2): 156171.

Petty JW, Palich LE, Hoy F, Longenecker JG (2012) Managing Small Business, An Entrepreneurial Emphasis (16 ${ }^{\text {th }}$ ed.). China: South-Western Cengage Learning.

Simrie M, Herrington M, Kew J, Turton N (2011) Global Entrepreneurship Monitor (GEM) Report. Cape Town: The University of Cape Town's Centre for Innovation and Entrepreneurship.

South Africa (1996) National Small Business Act, 102(32-31 Suppl.).South Africa: Trade and Industry.

South Africa (2004) National Small Business Amendment Act, 29 474(2710). Cape Town: Government Gazette.

SARS-South African Revenue Service (2011) Pocket Tax Guide, Budget 2011. Pretoria: SARS.

Steenekamp T (2011a). Introduction to taxation and tax equity. In: P Black, E Calitz, T Steenekamp (ed.). Public Economics. Cape Town: Oxford University Press Southern Africa (Pty) Ltd. 
Steenekamp T (2011b) Income taxation. In: P Black, E Calitz, T Steenekamp (ed.). Public Economics. Cape Town: Oxford University Press Southern Africa (Pty) Ltd.

Temkin S (2011) Business Day (33). In: Global Entrepreneurship Monitor (GEM). Cape Town: Graduate School of Business, University of Cape Town.

The World Bank (2012). Doing Business 2012 - Economy Profile South Africa. Washington: The International Bank for Reconstruction and Development/ the World Bank.

University of Pretoria (2009). Study Guide: M. Phil in Entrepreneurship and Small Business Management. Pretoria: Department of Business Management, University of Pretoria. 